\title{
PENGENDALIAN SAFETY STOCK GUNA MEMINIMALKAN BIAYA \\ PENYIMPANAN MELALUI PENDEKATAN SISTEM KANBAN SEBAGAI \\ PENDUKUNG SISTEM PRODUKSI JUST IN TIME
}

\author{
Umar Wiwi ${ }^{1}$, Eti Kristinawati ${ }^{2}$
}

\begin{abstract}
Based on ultimate goal of each company in gaining maximum profit with minimum total cost, then one of alternatives should be done in achieving this goal is avoiding excessive raw material stock resulting in high storage cost.

The object of this research is CV. Pabrik Mesin Guntur Malang, an industrial water pump company which is having difficulty in controlling raw material stock so that it often experiences abundant stocks. So, the problem is how to make stock control in order to reduce stocks amount that will result in storage cost reduction. Production System Just in Time applying Karban system, that has been being implemented this far by Toyota Motor Corporation, Japan, is proposed to be implemented in that company as well in order to reduce prevailing inefficiency result from this existing problem.

By applying Kanban system as support for the Production System Just in Time, it is shown that the system is capable in reducing stock amount by $77.56 \%$ for GTR type water pump and $89.59 \%$ for GTO type water pump. While reductions of storage cost achieved are $78.99 \%$ for GTR type water pump and $90.45 \%$ for GTO type water pump.
\end{abstract}

\section{Key Words : Just In Time, Kanban, Safety stock}

\section{PENDAHULUAN}

Salah satu penyebab permasalahan dalam sistem produksi adalah jumlah persediaan pengaman (safety stock) yang kurang tepat, Maka salah satu alternatif untuk memperbaiki hal tersebut adalah melalui perencanaan dan pengendalian persediaan sehingga dapat menurunkan biaya produksi serta dapat memenuhi permintaan konsumen secara tepat waktu.

CV. Pabrik Mesin Guntur adalah perusahaan yang bergerak dalam bidang industri pompa air dengan dua tipe, yaitu tipe GTR (pompa air dengan kipas tertutup) dan tipe GTO (pompa air dengan kipas terbuka)., Perusahan tersebut selalu berusaha memberikan pelayanan yang memuaskan kepada konsumen dengan ketepatan penyelesaian order. Perusahaan ini sering mengalami fluktuasi permintaan sehingga perusahaan harus mengadakan penumpukan bahan baku sebagai upaya pemenuhan permintaan konsumen yang mengakibatkan biaya penyimpanan terlalu tinggi. Berdasarkan kondisi-kondisi yang ada perusahaan mengaharapkan adanya perbaikan dalam sistem produksi, sehingga diharapkan dapat mengurangi persediaan yang tinggi. Untuk itu akan dicoba penerapan sistem produksi Just In Time (JT) dengan menggunakan sistem kanban 
dimana pemesanan bahan baku hanya dilakukan sejumlah yang diperlukan dan pada waktu yang diperlukan pula.

\section{TINJAUAN PUSTAKA}

\section{PERSEDIAAN}

Menurut Standar Akuntansi Keuangan (SAK) No. 14 (1995:142), persediaan didefinišikan sebagai aktiva yang tersedia untuk dijual dalam kegiatan usaha normal, dalam proses produksi dan atau dalam perjalanan, atau dalam bentuk bahan atau perlengkapan (supplies) untuk digunakan dalam proses

Adapun alasan diperlukannya persediaan antara lain :

1. Menghilangkan resiko keterlambatan datangnya bahan baku dari pemasok

2. Menghilangkan resiko bahwa bahan baku yang kita pesan ternyata cacat.

3. Menjamin kelancaran proses produksi.

Safety stock merupakan persediaan pengaman (tambahan) yang diadakan untuk menjaga kemungkinan terjadinya kekurangan bahan baku (stock-out) yang diakibatkan adanya penggunaan bahan baku yang lebih besar dari perkiraan semula, atau keterlambatan dalam penerimaan bahan baku yang dipesan.

Biaya penyimpanan $/$ unit $=($ Prosentase biaya penyimpanan x Harga bahan baku)

Total biaya penyimpanan $=(S S \times$ Biaya penyimpanan / unit)

\section{SISTEM PRODUKSI TOYOTA}

Sistem produksi Toyota dikembangkan dan dipromosikan oleh Toyota Motor Corporation ( TMC) Jepang akibat krisis minyak tahun 1973. Sistem ini bertujuan menyingkirkan berbagai jenis pemborosan dalam perusahaan melalui aktivitas perbaikan. Inovasi TMC ini kemudian diikuti oleh banyak perusahaan di Jepang, yang juga mulai diterapkan di perusahaan-perusahaan manufaktur di dunia guna peningkatan produktivitas dan kualitas.

Sistem produksi Toyota merupakan suatu teknologi manajemen komprehensip yang ditemukan Jepang seratus tahun setelah membuka diri terhadap dunia modern. Tujuan utama dari sistem produksi ini adalah pengurangan biaya atau perbaikan produktivitas yang dapat dicapai dengan menghilangkan berbagai macam pemborosan. Empat jenis pemborosan dalam operasi produksi antara lain :

1. Sumber daya produksi yang terlalu banyak

2. Produksi berlebihan

3. Persediaan berlebihan

4. Investasi modal yang tidak perlu

\section{Tujuan Utama Sistem Produksi Toyota}

1. Peningkatan Laba melalui Pengurangan Biaya

2. Penghilangan Produksi Berlebihan

3. Pengendalian Jumlah, Jaminan Mutu, dan Mengahargai Kemanusiaan

\section{Dua Tiang Utama Sistem Produksi} Toyota

1. Jidoka (Autonomasi)

2. Just In Time 


\section{SISTEM PRODUKSI JUST IN TIME}

\section{Definisi Sistem Produksi Just In Time}

\section{Menurut Kiyoshi Suzaki}

“ Just In Time berarti memproduksi barang yang diperlukan, pada waktu diperlukan, dalam jumlah diperlukan pada setiap tahap proses dengan cara yang paling ekonomis “.

Pada sistem pengendalian produksi biasa, penetapan waktu produksi dipenuhi dengan mengeluarkan berbagai jadwal produksi pada setiap proses, baik pada proses produksi maupun proses perakitan. Perakitan suku cadang seperti ini biasanya menggunakan sistem dorong, yaitu proses terdahulu memasok suku cadang pada proses berikutnya. Sebaliknya, sistem produksi Toyota bersifat revolusioner dimana proses berikutnya mengambil suku cadang dari proses terdahulu. Metode ini kemudian dikenal dengan sistem tarik. Karena hanya proses perakitan akhir yang mengetahui jumlah bahan baku yang diperlukan dengan tepat, maka lini rakit akhir ini yang akan pergi ke proses terdahulu untuk mendapatkan bahan baku dalam jumlah dan waktu yang diperlukan. Selanjutnya proses terdahulu akan memproduksi sejumlah suku cadang yang diambil lini rakit.

\section{Tujuan Sistem Produksi Just In Time}

Tujuan sistem produksi JIT adalah mencapai efisiensi dengan cara menekan tingkat persediaan yang dimiliki serendah mungkin, sehingga pengurangan biaya penyimpanan dan rasio pengembalian modal akan meningkat. Usaha untuk mencapai tujuan tersebut antara lain
1. Menyatukan dan mengoptimalkan setiap tahap dari proses manufaktur

2. Menghasilkan produk yang berkualitas

3. Mengurangi biaya manufaktur

4. Menghasilkan produk hanya untuk permintaan

5. Menjaga perjanjian yang dibuat antara customer dan pemasok

\section{Konsep Sistem Produksi Just In Time}

Tujuan akhir sistem produksi JIT adalah menekan biaya produksi seminimal mungkin dengan jalan menghilangkan berbagai pemborosan sehingga dapat diperoleh suatu peningkatan keuntungan.

Hal-hal yang dapat dilakukan untuk mengurangi pemborosan, antara lain :

1. Mengurangi atau menghilangkan produksi berlebihan

2. Meniadakan barang dalam proses pada setiap workstation atau tahapan pengolahan produk (konsep persediaan nol).

3. Mengurangi atau meniadakan lead time produksi (konsep waktu tunggu nol).

Dalam sistem produksi Toyota, sistem kanban di dukung oleh hal-hal berikut :

1. Pelancaran Produksi

2. Pembakuan Pekerjaan (Operasi)

3. Pengurangan Waktu Penyiapan ( Set Up )

4. Aktivitas Perbaikan

5. Autonomasi

6. Rancangan tata ruang mesin 


\section{KANBAN}

Kanban merupakan suatu alat untuk mencapai produksi JIT yang berupa suatu kartu yang berisi tentang informasi dan biasanya dimasukkan dalam amplop vinil berbentuk empat persegi panjang.

\section{Fungsi Kanban}

Sistem kanban dapat berfungsi sebagai :

1. Perintah antara produksi dan pengiriman

2. Pengendalian diri sendiri untuk mencegah produksi yang berlebihan

3. Pengendalian Visual

4. Perbaikan proses dan operasi manual

5. Pengurangan biaya pengelolaan

\section{Klasifikasi Kanban}

Kanban dibedakan menjadi 2, yaitu :

1. Kanban Perintah Produksi (Kanban dalam pengolahan)

- Kanban Produksi (biasa)

- Kanban Segitiga

2. Kanban Pengambilan

- Kanban Pengambilan Antar Proses

- Kanban Pemasok

\begin{tabular}{|c|c|c|c|}
\hline \multicolumn{3}{|l|}{ No.Rak } & Proses Terdahulu \\
\hline \multicolumn{3}{|c|}{ Gudang : 5E215 No. Belakang : A $2-15$} & PENEMPAAN \\
\hline \multicolumn{3}{|c|}{ No. Barang : 35670507} & B-2 \\
\hline \multirow{2}{*}{\multicolumn{3}{|c|}{$\begin{array}{l}\text { Nama Barang : Roda Gigi Pengerak } \\
\text { Jenis Mobil : SX50OB }\end{array}$}} & Proses berikut \\
\hline & & & \multirow{3}{*}{$\begin{array}{l}\text { PENGERJAAN } \\
\text { MESIN } \\
\text { M-6 }\end{array}$} \\
\hline Kapasitas Kotak & Jenis Kotak & No Keluaran & \\
\hline 20 & B & $4 / 8$ & \\
\hline
\end{tabular}

Gambar 1

Kanban Pengambilan
NO. RAK

Gudang : F-26-18 No. Belakang Barang : A5-34

No. Barang : $56790-321$

Nama Barang : Poros Engkol

Jenis Mobil : SX50BC-150

PROSES

Pengerjaan

Mesin

SB -8

\section{Gambar 2 \\ Kanban Perintah Produksi}

\section{Penentuan Jumlah Kartu Kanban}

Sistem Pengambilan Jumlah Tetap Siklus

Tidak Tetap

1. Bila ukuran lot besar dan kegiatan penyiapan belum sempurna.

$$
N=\frac{\left(\frac{D}{S}\right) x(d x \alpha)}{K}
$$

dimana :

$\mathrm{N}=$ Jumlah kanban

$\mathrm{D}=$ Kebutuhan bulanan

$\mathrm{S}=$ Jumlah penyiapan bulanan

$\mathrm{d}=$ Kebutuhan per hari

$\alpha=$ Koefisien pengaman

$\mathrm{K}=$ Kapasitas peti kemas

2. Bila metode penyiapan telah sempurna dan ukuran lot dalam jumlah kecil

$$
N=\frac{d x W p x(1+\alpha)}{K}
$$

dimana :

$\mathrm{Wp}=$ Waktu pemesanan

Waktu pemesanan dalam rumus ini ditentukan dengan :

$$
W p=W o+W t+W k+W b
$$




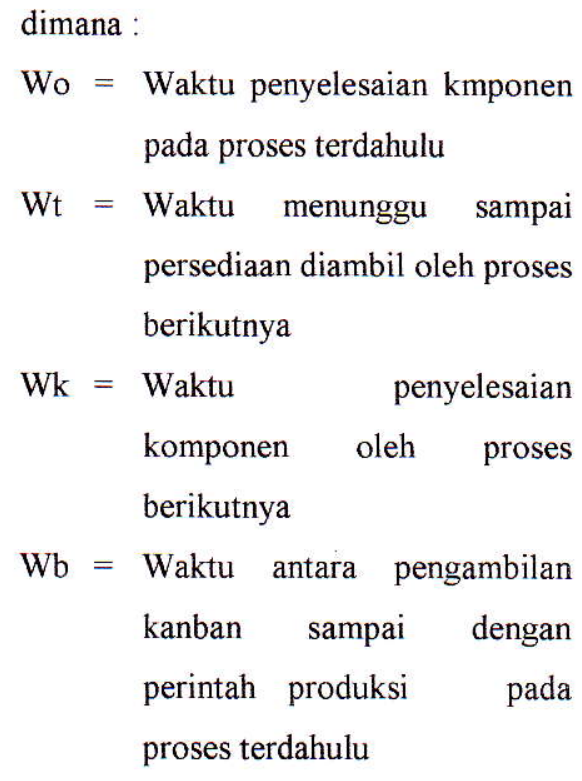

Sistem Pengambilan Jumlah Tidak Tetap

\section{Siklus Tetap}

$$
\begin{aligned}
& N=\frac{d x(c+W p+\alpha)}{K} \\
& \text { dimana : } \\
& \mathrm{N}=\text { Jumlah keseluruhan kanban } \\
& \mathrm{d}=\text { Kebutuhan harian } \\
& \mathrm{c}=\text { Siklus pesanan } \\
& \mathrm{Wp}=\text { Waktu pemesanan } \\
& \mathrm{K}=\text { Waktu pemesanan } \\
& \alpha=\text { Koefisien pengaman }
\end{aligned}
$$

\section{Kanban Pemasok}

Faktor yang menentukan jumlah kartu kanban pemasok, antara lain :

1. Kapasitas peti kemas

2. Siklus pemesanan

3. Waktu pemesanan

4. Frekuensi pengangkutan per hari

5. Selang waktu pengangkutan

6. Koefisien pengaman

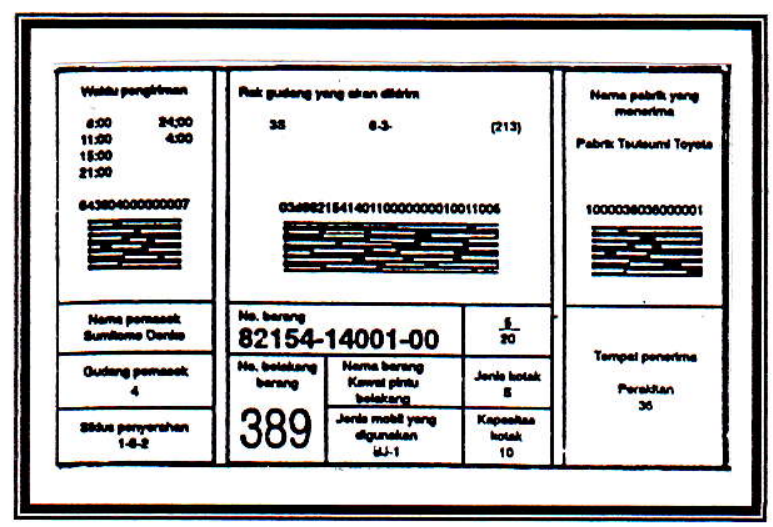

\section{Gambar 3 \\ Kanban Pemasok}

\section{Penentuan jumlah kartu kanban pemasok}

$$
N=\frac{d \times(c+W p+\alpha)}{K}
$$

dimana :

$$
\begin{aligned}
& \mathrm{N}=\text { Jumlah keseluruhan kanban } \\
& \mathrm{d}=\text { Kebutuhan harian } \\
& \mathrm{c}=\text { Siklus pesanan } \\
& \mathrm{Wp}=\text { Waktu pemesanan } \\
& \mathrm{K}=\text { Kapasitas peti kemas } \\
& \alpha=\text { Koefisien pengaman }
\end{aligned}
$$

Siklus pemesanan pada pemasok dihitung dengan rumus :

$$
c=\frac{\llbracket A \rrbracket}{B}
$$

$$
\begin{aligned}
\mathrm{A}= & \text { Jumlah hari yang digunakan untuk } \\
& \text { sekali pesan }- \text { Waktu pengangkutan } \\
\mathrm{B}= & \text { Frekuensi pengangkutan per hari }
\end{aligned}
$$

Sedangkan waktu pemesanan pada pemasok dapat diukur dengan menggunakan rumus :

$$
W p=c \times C
$$


dimana :
c $=$ Siklus pemesanan
$\mathrm{C}=$ Selang waktu pengangkutan

Dengan memperhatikan ketiga rumus diatas, maka rumus jumlah keseluruhan kanban pemasok dapat diturunkan sebagai berikut :

$$
\begin{aligned}
& N=\frac{d x(c x W p \times \alpha)}{K} \\
& N=\frac{d}{K} x\left\{\frac{A}{B}+\left(\frac{A}{B} x C\right)+\alpha\right\} \\
& N=\frac{d}{K} x\left\{\frac{A}{B} x(C+1)+\alpha\right\}
\end{aligned}
$$

Selanjutnya dengan tetap memperhatikan rumus diatas, jumlah pesanan dengan sistem kanban dapat ditentukan dengan rumus :

Jumlah pesanan $=($ jumlah kanban yang dilepas $x$ Kapasitas peti kemas , pada waktu pengumpulan kanban.

\section{METODOLOGI PENELITIAN}

\section{Jenis Data Yang Diperlukan}

Data yang diperlukan meliputi data jenis produk, komposisi bahan, jenis mesin dan peralatan, proses produksi dan waktunya, alternatif perusahaan, stock awal dan harga bahan baku, harga jual produk, pemasok bahan baku, serta frekuensi transportasi bahan baku.

\section{Tahapan Pengolahan Data}

Proses pengolahan data meliputi beberapa tahapan, antara lain :

1. Analisa safety stock dan biaya penyimpanan sebelum penerapan sistem kanban.

- Jumlah persediaan pengaman (safety stock)

- Biaya penyimpanan bahan baku

2. Analisa safety stock dan biaya penyimpanan sesudah penerapan sistem kanban

- Jumlah keseluruhan kanban

- Jumlah persediaan pengaman (safety stock)

- Biaya penyimpanan bahan baku berdasarkan sistem kanban

- Peredaran kanban pemasok

3. Perbandingan safety stock dan biaya penyimpanan sebelum dan sesudah penerapan sistem kanban

\section{HASIL DAN PEMBAHASAN}

Berdasarkan analisa yang dilakukan, maka didapatkan hasil sebagai berikut :

\section{Analisa Safety Stock dan Biaya Penyimpanan Sebelum Penerapan Sistem Kanban}

Jml stock bahan baku yg ada

Jml stock $=$

Jml keb. Bahan baku per pompa 
Tabel 1

Jumlah Stock Produksi

Pompa Air Tipe GTR dan GTO

\begin{tabular}{|c|l|c|c|}
\hline \multirow{2}{*}{ No } & \multicolumn{1}{|c|}{ Nama Bahan } & \multicolumn{2}{c|}{$\begin{array}{c}\text { Stock Produksi } \\
\text { (unit) }\end{array}$} \\
\cline { 3 - 4 } & & GTR & GTO \\
\hline 1 & Plendes tekan dan paking & 100 & 50 \\
\hline 2 & Tutup lubang pancingan & 70 & 39 \\
\hline 3 & Rumah pompa & 65 & 65 \\
\hline 4 & Plendes dan katup hisap & 98 & 54 \\
\hline 5 & Ttp pencerat dan paking & 100 & 50 \\
\hline 6 & Ring & 160 & 160 \\
\hline 7 & Kipas pompa & 75 & 44 \\
\hline 8 & O-ring & 75 & 75 \\
\hline 9 & Dudukan poros & 65 & 65 \\
\hline 10 & Poros & 70 & 70 \\
\hline 11 & Roda transmisi & 70 & 70 \\
\hline 12 & Reames & 75 & 75 \\
\hline 13 & Pemantul air & 90 & 90 \\
\hline 14 & Aksesoris & 69 & 69 \\
\hline 15 & Bantalan peluru & 75 & 75 \\
\hline 16 & Mur dan baut & 59 & 59 \\
\hline
\end{tabular}

$$
\begin{aligned}
& \text { Jiml prod. } \\
& \text { Per hari }
\end{aligned}=\operatorname{JmlTK} x \frac{\text { Waktu efektif per hari }}{\text { Waktu proses prod. Per hari }}
$$

Pompa GTR $=55 \times \frac{390^{\prime}}{450^{\prime}}=47,667$

$\approx 48$ pompa per hari

$\begin{aligned} \text { Pompa GTO } & =25 \times \frac{390^{\prime}}{465^{\prime}}=20,968 \\ & \approx 21 \text { pompa per hari }\end{aligned}$

Safety stock $=$ Stock per hari-Jumlah produksi per hari

\section{Tabel 2}

Jumlah Safety Stock Bahan Baku Pompa Air Tipe GTR dan GTO

\begin{tabular}{|c|l|c|c|}
\hline \multirow{2}{*}{} & \multicolumn{1}{|c|}{ Nama Bahan } & \multicolumn{2}{|c|}{$\begin{array}{c}\text { Safety Stock } \\
\text { (unit) }\end{array}$} \\
\cline { 3 - 4 } & & GTR & GTO \\
\hline 1 & $\begin{array}{l}\text { Plendes tekan dan } \\
\text { paking }\end{array}$ & 52 & 29 \\
\hline 2 & Tutup lubang pancingan & 22 & 49 \\
\hline 3 & Rumah pompa & 17 & 18 \\
\hline 4 & Plendes dan katup hisap & 50 & 33 \\
\hline 5 & Ttp pencerat dan paking & 52 & 29 \\
\hline 6 & Ring & 112 & 139 \\
\hline 7 & Kipas pompa & 27 & 23 \\
\hline 8 & O-ring & 27 & 54 \\
\hline
\end{tabular}

\begin{tabular}{|c|l|c|c|}
\hline \multirow{2}{*}{} & & \multicolumn{2}{|c|}{$\begin{array}{c}\text { Safety Stock } \\
\text { (unit) }\end{array}$} \\
\cline { 3 - 4 } & & GTR & GTO \\
\hline 9 & Dudukan poros & 17 & 44 \\
\hline 10 & Poros & 22 & 49 \\
\hline 11 & Roda transmisi & 22 & 49 \\
\hline 12 & Reames & 27 & 54 \\
\hline 13 & Pemantul air & 42 & 69 \\
\hline 14 & Aksesoris & 21 & 48 \\
\hline 15 & Bantalan peluru & 27 & 54 \\
\hline 16 & Mur dan baut & 11 & 38 \\
\hline
\end{tabular}

Biaya penyimpanan bahan baku

$$
=\left(\frac{H \arg \text { a bahan baku }}{H \arg \text { a produk }}\right) \times \text { Biaya penyimpanan per tahun }
$$

Total biaya penyimpanan

$=$ Jumlah persediaanx Biaya penyimpana bahan baku

\section{Tabel 3}

Biaya Penyimpanan Bahan Baku Pompa Air Tipe GTR dan GTO Berdasarkan Jumlah Persediaan (Safety Stock)

\begin{tabular}{|c|l|r|r|}
\hline \multirow{2}{*}{ No } & \multicolumn{1}{|c|}{ Nama Bahan } & \multicolumn{2}{c|}{$\begin{array}{c}\text { Biaya Penyimpanan } \\
\text { Per Tahun (Rupiah) }\end{array}$} \\
\cline { 3 - 4 } & & \multicolumn{1}{c|}{ GTR } & \multicolumn{1}{c|}{ GTO } \\
\hline 1 & Plendes tekan \& paking & 178.750 & 90.625 \\
\hline 2 & Tutup lubang pancingan & 34.375 & 76.563 \\
\hline 3 & Rumah pompa & 318.750 & 337.500 \\
\hline 4 & Plendes dan katup hisap & 325.000 & 210.375 \\
\hline 5 & Ttp pencerat dan paking & 92.950 & 50.025 \\
\hline 6 & Ring & 196.000 & 243.250 \\
\hline 7 & Kipas pompa & 370.575 & 232.875 \\
\hline 8 & O-ring & 5.569 & 11.137 \\
\hline 9 & Dudukan poros & 175.525 & 454.300 \\
\hline 10 & Poros & 163.900 & 290.550 \\
\hline 11 & Roda transmisi & 38.500 & 68.250 \\
\hline 12 & Reames & 125.550 & 251.100 \\
\hline 13 & Pemantul air & 15.750 & 25.875 \\
\hline 14 & Aksesoris & 131.250 & 300.000 \\
\hline 15 & Bantalan peluru & 84.375 & 168.750 \\
\hline 16 & Mur dan baut & 24.200 & 110.200 \\
\hline \multicolumn{2}{|l|}{ Total $=$} & $\mathbf{2 . 2 8 1 . 0 1 9}$ & $\mathbf{2 . 9 2 1 . 3 7 5}$ \\
\hline
\end{tabular}

\section{Analisa Safety Stock dan Biaya Penyimpanan Sesudah Penerapan Sistem Kanban}

Jumlah keseluruhan kanban :

$$
N=\frac{d}{K} \times\left\{\frac{A}{B}(C+1)+\alpha\right\}
$$




\section{a) Pemasok AFF Surabaya}

- Jumlah hari dalam pengiriman $(\mathrm{A})=$ 1

- Frekuensi pengiriman dalam jumlah hari pengiriman $(\mathrm{B})=3$

- Selang waktu pengangkutan $(C)=2$

- Kuantitas koefisien keamanan $(\alpha)$ untuk :

$$
\begin{aligned}
& \text { Pompa GTR }=0,04 \times 48=1,92 \approx 2 \\
& \text { Pompa GTO }=0,04 \times 21=0,84 \approx 1
\end{aligned}
$$

Tabel 4

Jumlah Kanban Pemasok AFF Surabaya Pompa Air Tipe GTR dan GTO

\begin{tabular}{|c|c|c|c|}
\hline \multirow{2}{*}{ No } & \multirow{2}{*}{ Nama Bahan } & \multicolumn{2}{|c|}{$\begin{array}{c}\text { Jumlah kanban } \\
\text { (unit) }\end{array}$} \\
\cline { 3 - 4 } & & GTR & GTO \\
\hline 1 & Rumah poros & 13 & 6 \\
\hline 2 & Kipas pompa & 9 & 4 \\
\hline 3 & Dudukan poros & 9 & 4 \\
\hline 4 & Poros & 5 & 2 \\
\hline
\end{tabular}

Dengan adanya penerapan sistem kanban diperoleh frekuensi transportasi pengiriman bahan baku per minggunya ( 5 hari) sebanyak 15 kali dengan biaya transportasi include terhadap harga jual per bahan baku dari pemasok AFF Surabaya.

\section{b) Pemasok Hiram Foundries Malang}

- Jumlah hari dalam pengiriman $(\mathrm{A})=$ 1

- Frekuensi pengiriman dalam jumlah hari pengiriman $(\mathrm{B})=3$

- Selang waktu pengangkutan $(\mathrm{C})=2$

- Kuantitas koefisien keamanan $(\alpha)$ untuk :

Pompa GTR $=0,06 \times 48=2,88 \approx 3$

Pompa GTO $=0,06 \times 21=1,26 \approx 2$
Tabel 5

Jumlah Kanban Pemasok H. Foundries Malang Pompa Air Tipe GTR dan GTO

\begin{tabular}{|c|l|c|c|}
\hline \multirow{2}{*}{ No } & \multicolumn{1}{|c|}{ Nama Bahan } & \multicolumn{2}{|c|}{ Jumlah kanban (unit) } \\
\cline { 3 - 4 } & & GTR & GTO \\
\hline 1 & Plendes tekan \& paking & 6 & 3 \\
\hline 2 & Tutup lubang pancingan & 5 & 2 \\
\hline 3 & Plendes dan katup hisap & 6 & 3 \\
\hline 4 & Ttp pencerat dan paking & 5 & 2 \\
\hline 5 & Ring & 3 & 2 \\
\hline 6 & Roda transmisi & 6 & 3 \\
\hline 7 & Aksesoris & 11 & 5 \\
\hline 8 & Bantalan peluru & 4 & 2 \\
\hline 9 & Mur dan baut & 5 & 2 \\
\hline
\end{tabular}

Dengan adanya penerapan sistem kanban diperoleh frekuensi transportasi pengiriman bahan baku per minggunya ( 5 hari) sebanyak 15 kali dengan biaya transportasi include terhadap harga jual per bahan baku dari pemasok Hiram Foundries Malang.

\section{c) Pemasok Thomas Jaya Malang}

- Jumlah hari dalam pengiriman $(\mathrm{A})=$ 1

- Frekuensi pengiriman dalam jumlah hari pengiriman $(\mathrm{B})=2$

- Selang waktu pengangkutan $(C)=1$

- Kuantitas koefisien keamanan $(\alpha)$ untuk :

Pompa GTR $=0,06 \times 48=2,88 \approx 3$

Pompa GTO $=0,06 \times 21=1,26 \approx 2$

Tabel 6

Jumlah Kanban Pemasok Thomas Jaya Malang Pompa Air Tipe GTR dan GTO

\begin{tabular}{|c|l|c|c|}
\hline \multirow{2}{*}{ No } & \multirow{2}{*}{ Nama Bahan } & \multicolumn{2}{|c|}{$\begin{array}{c}\text { Jumlah kanban } \\
\text { (unit) }\end{array}$} \\
\cline { 3 - 4 } & & GTR & GTO \\
\hline 1 & O-ring & 4 & 2 \\
\hline 2 & Reames & 6 & 3 \\
\hline 3 & Pemantul air & 6 & 3 \\
\hline
\end{tabular}


Dengan adanya penerapan sistem kanban diperoleh frekuensi transportasi pengiriman bahan baku per minggunya ( 5 hari) sebanyak 10 kali dengan biaya transportasi include terhadap harga jual per bahan baku dari pemasok Thomas Jaya Malang.

Safety stock $=($ Jumlah keseluruhan kanban $x$ Kapasitas peti kemas) -

( Kebutuhan harian + Kuantitas koefisien pengaman)

Tabel 7

Jumlah Safety Stock Bahan Baku Pompa Air Tipe GTR dan GTO

\begin{tabular}{|c|l|c|c|}
\hline \multirow{2}{*}{ No } & \multicolumn{1}{|c|}{ Nama Bahan } & \multicolumn{2}{|c|}{ Safety Stock (unit) } \\
\cline { 3 - 4 } & & GTR & GTO \\
\hline 1 & Plendes tekan \& paking & 9 & 7 \\
\hline 2 & Tutup lubang pancingan & 9 & 1 \\
\hline 3 & Rumah pompa & 2 & 2 \\
\hline 4 & Plendes dan katup hisap & 9 & 7 \\
\hline 5 & Ttp pencerat dan paking & 9 & 1 \\
\hline 6 & Ring & 9 & 17 \\
\hline 7 & Kipas pompa & 4 & 2 \\
\hline 8 & O-ring & 9 & 7 \\
\hline 9 & Dudukan poros & 4 & 2 \\
\hline 10 & Poros & 10 & 2 \\
\hline 11 & Roda transmisi & 9 & 7 \\
\hline 12 & Reames & 9 & 7 \\
\hline 13 & Pemantul air & 9 & 7 \\
\hline 14 & Aksesoris & 4 & 2 \\
\hline 15 & Bantalan peluru & 9 & 7 \\
\hline 16 & Mur dan baut & 9 & 1 \\
\hline
\end{tabular}

Total biaya penyimpanan $=S S \quad x$ Biaya penyimpanan bahan baku

Tabel 8

Biaya Penyimpanan Bahan Baku Pompa Air Tipe GTR dan GTO

\begin{tabular}{|c|c|c|c|}
\hline No & Nama Bahan & \multicolumn{2}{|c|}{$\begin{array}{c}\text { Biaya Penyimpanan } \\
\text { Per Tahun (Rupiah) }\end{array}$} \\
\cline { 3 - 4 } & & GTR & GTO \\
\hline 1 & Plendes tekan \& paking & 30.938 & 21.875 \\
\hline 2 & Tutup lubang pancingan & 14.062 & 1.562 \\
\hline 3 & Rumah pompa & 37.500 & 37.500 \\
\hline 4 & Plendes dan katup hisap & 58.500 & 44.625 \\
\hline 5 & Ttp pencerat dan paking & 16.088 & 1.725 \\
\hline
\end{tabular}

\begin{tabular}{|c|c|c|c|}
\hline \multirow[t]{2}{*}{ No } & \multirow[t]{2}{*}{ Nama Bahan } & \multicolumn{2}{|c|}{$\begin{array}{l}\text { Biaya Penyimpanan } \\
\text { Per Tahun (Rupiah) }\end{array}$} \\
\hline & & GTR & GTO \\
\hline 6 & Ring & 15.750 & 29.750 \\
\hline 7 & Kipas pompa & 54.900 & 20.250 \\
\hline 8 & $O$-ring & 1.856 & 1.444 \\
\hline 9 & Dudukan poros & 41.300 & 20.650 \\
\hline 10 & Poros & 74.500 & 14.900 \\
\hline 11 & Roda transmisi & 15.750 & 12.250 \\
\hline 12 & Reames & 41.850 & 32.550 \\
\hline 13 & Pemantul air & 3.375 & 2.625 \\
\hline 14 & Aksesoris & 25.000 & 12.500 \\
\hline 15 & Bantalan peluru & 28.125 & 21.875 \\
\hline 16 & Mur dan baut & 19.800 & 2.900 \\
\hline & Total : & 479.294 & 278.981 \\
\hline
\end{tabular}

Prosentase penurunan jumlah persediaan pengaman (safety stock ) dan biaya penyimpanan sesudah penerapan sistem kanban adalah sebagai berikut :

1. Berdasarkan jumlah persediaan pengaman (safety stock)

- Pompa air tipe GTR

$$
\begin{aligned}
\text { Pr osentase penrunan }= & \left\{\frac{548-123}{548}\right\} \times 100 \% \\
& =77,56 \%
\end{aligned}
$$

- Pompa air tipe GTO

$$
\begin{gathered}
\text { Pr osentase pennuman }=\left\{\frac{759-79}{759}\right\} \times 100 \% \\
=89,59 \%
\end{gathered}
$$

2. Berdasarkan biaya penyimpanan

- Pompa air tipe GTR

Pr osentase penrunan $=\left\{\frac{2281019-479294}{2281019}\right\} \times 100 \%$

$$
=78,99 \%
$$

- Pompa air tipe GTO

Pr osentase penrunan $=\left\{\frac{2921375-278981}{2921375}\right\} \times 100 \%$

$$
=90,45 \%
$$




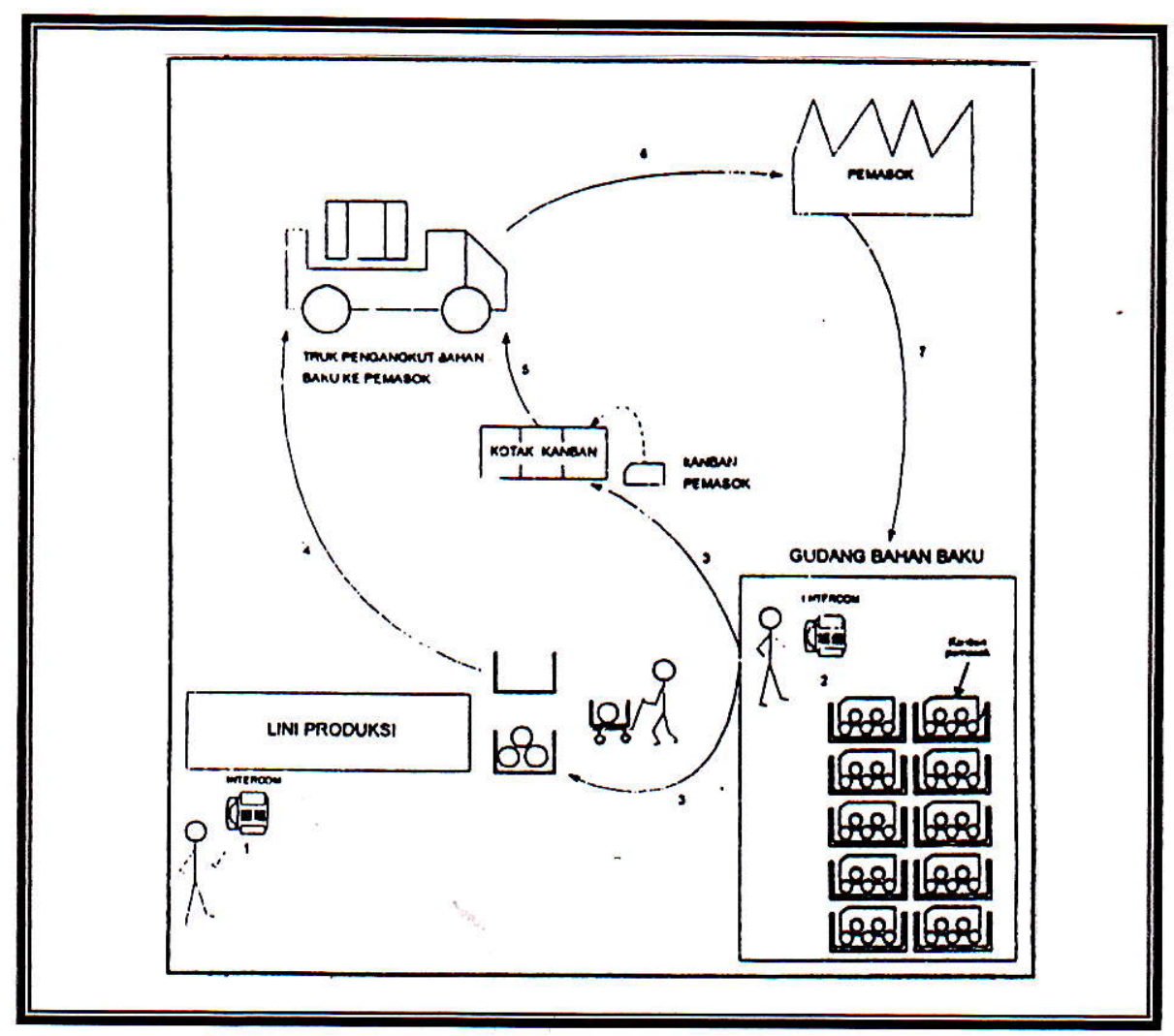

Gambar 4

Peredaran Kanban Pemasok

\section{KESIMPULAN}

Dari analisis data secara keseluruhan dapat disimpulkan beberapa hal antara lain :

1. Sebelum menerapkan sistem kanban, perusahaan sering mengalami penumpukan bahan baku sebagai upaya pemenuhan kebutuhan konsumen. Namun sesudah menerapkan sistem kanban sebagai pendukung sistem produksi Just In Time (JT) diperoleh jumlah persediaan pengaman (safety stock) yang sesuai dengan kapasitas produksi, sehingga tidak perlu adanya penumpukan bahan baku yang berlebihan yang dapat mengakibatkan tingginya biaya penyimpanan.

2. Berdasarkan analisa yang dilakukan diketahui bahwa terjadi penurunan jumlah persediaan pengaman (safety stock) sesudah menerapkan sistem kanban, yaitu sebesar $77,56 \%$ untuk pompa air tipe GTR dan $\quad 89,59 \%$ untuk pompa air tipe GTO.

3. Berdasarkan analisa yang dilakukan diketahui pula terjadi penurunan biaya penyimpanan sesudah menerapkan sistem kanban, yaitu sebesar 78,99\% untuk pompa air tipe GTR dan 90,45 $\%$ untuk pompa air tipe GTO. 
4. Dengan penerapan sistem kanban diperoleh penurunan frekuensi transportasi pengiriman bahan baku dari pemasok ke perusahaan induk sehingga waktu dan biaya transportasi yang diperlukan menjadi lebih efektif dan efisien.

\section{DAFTAR PUSTAKA}

Asri, Marwan, Handoko, T. Hani dan Subagyo, 1984. Dasar-Dasar Riset Operasi, BPFE, Yogyakarta,

Monden, Yasuhiro, 1995, Sistem Produksi Toyota, Buku I dan II, PT. Pustaka Binaman Pressindo, Jakarta.
Ohno, Taichi, 1995, Just In Time Dalam Sistem Produksi Toyota, PT. Pustaka Binaman Pressindo, Jakarta.

Schiederjans, Marc J., 1992, Topics In JustIn Time Management, University of Nebraska, Lincoln.

Marbun, B.N, 1984, Manajemen Jepang,

PT. Pustaka Binaman Pressindo, Jakarta.

Suzaki, Kiyoshi, 1992, Tantangan Industri Manufaktur (Penerapan Perbaikan Berkesinambungan), Toyota Motor Corporation. 